\title{
Investigation of pre-service physical education teachers' epistemological and pedagogical beliefs
}

\author{
Tarık Balc1 $^{1}$ and Hatice Çamlıyer ${ }^{2}$ \\ ${ }^{1}$ Balkkesir University, Faculty of Sport Sciences, Turkey (ORCID: 0000-0002-9372-9487) \\ Independent Researcher, Turkey (ORCID: 0000-0003-1255-875X)
}

\begin{abstract}
The aim of this study was to examine pre-service physical education teachers' epistemological and pedagogical beliefs and to reveal the relationship between those beliefs. The participants in the study were 333 pre-service teachers studying in physical education and sports teaching departments. The epistemological beliefs questionnaire, and teaching and learning conceptions questionnaire were used as the data collection tools. In the analysis of the data, descriptive statistics, independent samples t-test, Pearson correlation analysis and path analysis were applied. It was determined that the pre-service physical education teachers' mean scores for learning process-doubting authority/expert knowledge, learning effort and constructivist conception were high, while their scores for innate/fixed ability, certainty of knowledge and traditional conception were moderate. According to the path analysis results, it was revealed that their innate/fixed ability and certainty of knowledge beliefs positively predicted the traditional conception, while their learning process-doubting authority/expert knowledge and learning effort beliefs positively predicted the constructivist conception. As a result of the research, it was determined that generally, the pre-service physical education teachers believed in the importance of effort and process in learning, and that they adopted a constructivist conception. Furthermore, it was revealed that epistemological beliefs are an important variable in predicting pedagogical beliefs.
\end{abstract}

Keywords: Epistemological beliefs; Pedagogical beliefs; Pre-service teachers; Teaching-learning conceptions

Article History: Submitted 6 June 2021; Revised 25 January 2022; Published online 8 February 2022

\section{Introduction}

Beliefs are perceived as internal acceptances or propositions that are assumed by individuals to be "correct" without question and that affect their perception, interpretation and behaviour patterns related to every kind of event, phenomenon, person or object that they encounter in their daily lives. Since beliefs have an important effect on individuals' ideas, behaviours and judgements, various dimensions of belief have always been examined and been the subject of research studies. One of the most important of these beliefs are epistemological beliefs (Köse \& Dinç, 2012). Epistemological beliefs are expressed as individuals' personal beliefs about the nature of knowledge and knowing (Brunning et al., 2004; Hofer \& Pintrich, 1997; Schommer, 1990, 1994). According to another definition, epistemological beliefs are stated to be subjective beliefs related to

Address of Corresponding Author

Tarık Balcı, Department of Physical Education and Sports Teaching, Faculty of Sport Sciences, Balıkesir University, Turkey.

$\triangle$ baun.tarikbalci@gmail.com

How to cite: Balc1, T. \& Çamliyer, H. (2022). Investigation of pre-service physical education teachers' epistemological and pedagogical beliefs. Journal of Pedagogical Research, 6(1), 40-56. https:// dx.doi.org/10.33902/JPR.2022175429 
what knowledge is, and how knowing and learning occur (Deryakulu, 2017). Questions such as how individuals acquire knowledge, on which reasons they base their beliefs in the correctness or incorrectness of knowledge, and how "knowing" is identified within cognitive structures are gaining increasing value in today's society (Bahçıvan, 2017). In this context, the epistemological beliefs of students, teachers and pre-service teachers have recently become an important endeavour and an attractive research subject in the field of education.

Research studies conducted on epistemological beliefs have contributed to better understanding of ideas about knowledge and knowing (Hofer \& Pintrich, 1997; Hofer, 2002). According to Schommer (1990, 1994) and Schommer-Aikins (2002), people with sophisticated epistemological beliefs believe that knowledge develops and that only a very small part of it can be classified as fixed/unchangeable. Moreover, individuals with sophisticated epistemological beliefs approach the things that they read in a critical way. However, individuals with naïve epistemological beliefs believe that a large part of knowledge is certain/absolute and that only a small part of knowledge changes or can be changed. Furthermore, individuals who tend to have naïve epistemological beliefs do not approach the things that they read in a critical way and are more inclined to be affected by the things that they read.

Educators and researchers frequently state that teachers' belief and value systems shape their understandings of teaching, and that this situation has an effect on their teaching strategies and classroom performance (Cheng et al., 2009). Studies conducted in this context reveal that teachers' and pre-service teachers' epistemological beliefs have a determining effect on their teaching practices and understandings (Kang \& Wallace, 2005; Schraw \& Olafson, 2003; Sinatra \& Kardash, 2004; Tsai, 2007; Yadav \& Koehler, 2007). For example, Schraw and Olafson (2003) examined the relationship between teachers' epistemological world views and their in-class teaching practices by using an interview method, and they asserted that teachers with sophisticated (contextualrelativist) epistemological beliefs mostly display constructivist teaching practices, while teachers with naïve (realist) epistemological beliefs mostly exhibit information-relaying, traditional teaching practices. Kang and Wallace (2005) examined the epistemological beliefs and laboratory activities of science teachers. In the study, it was stated that teachers who have naïve epistemological beliefs, and who see science as knowledge based on facts whose truth cannot be questioned, regard themselves and their students as receivers/consumers of scientific knowledge and never use teaching practices based on deep cognitive processes in the learning environment. On the other hand, they stated that teachers who have sophisticated epistemological beliefs belief in multiple facts that may be valid depending on the context, express science as a problem-solving process, provide their students with open-ended questions that support multiple answers and methods, and, while performing these practices, consider their students as scientists and support them with regard to doing science. In the study by Yadav and Koehler (2007), it was determined that epistemological beliefs are generally consistent with the preferred teaching practice. They stated that pre-service teachers who believed that knowledge is objective and also that learning ability is innate tended to prefer teacher-centred practices, while pre-service teachers who believed that knowledge is relative/subjective and also that learning ability can be changed/developed mostly preferred student-centred teaching practices.

Another important factor affecting teachers' behaviours in the education environment is teaching-learning conceptions or pedagogical beliefs. These beliefs involve the meaning of teaching and learning, as well as the roles of the teacher and students (Chan \& Elliott, 2004). There are two main conceptions in learning-teaching, namely, the traditional/transmissive/teachercentred conception and the constructivist/progressive/student-centred conception (Aypay, 2011a; Chan \& Elliott, 2004; Teo et al., 2008; Wong et al., 2009). In the traditional conception, education is teacher-centred. In the teacher, student and knowledge triangle, the teacher is in the position of relaying information, while the student is in the position of consuming/receiving the information which is found ready-made in the outside world (Özden, 2014). Rote learning instead of meaningful learning is at the forefront in the learning environment (Baş \& Beyhan, 2013). 
According to this conception, information is independent of the individual and is found readymade in the outside world (Yurdakul, 2015). In the constructivist conception, however, education is conducted in a student-centred way. It is the student who investigates, interprets and analyses the information. In this conception, instead of the information being relayed to the student or being memorised by the student, it should be structured and transferred (Akınoğlu, 2018). According to Cevizci (2018), the most important idea that determines the constructivist conception is the idea whereby problem-solving lies at the basis of learning, thinking and therefore development.

One of the main reasons for the examination of epistemological beliefs is the potential effect of these beliefs on the conceptions of teaching and learning (Otting et al., 2010). Özden (2014) stated that educators' beliefs in the nature of knowledge will affect their perspective on education and instruction. Therefore, today's researchers show great interest in pre-service teachers' epistemological and pedagogical beliefs, and it is possible to find many studies conducted on this subject in the literature. According to Dimov et al. (2015), the reason for this interest is the acceptance that epistemological belief and teaching-learning conceptions, or in other words, pedagogical beliefs, are related to each other. Within this framework, when studies made with preservice teachers are examined, it is seen that epistemological beliefs and teaching-learning conceptions are correlated with each other, and that furthermore, epistemological beliefs have an important effect on constructivist and traditional conceptions (Abakay, 2013; Akyıldız, 2018; Aypay, 2011a; Chai \& Khine, 2008; Chai et al., 2009, 2010; Chan \& Elliott, 2004; Cheng et al., 2009; Ketabi et al., 2014; Otting et al., 2010; Tezci et al., 2016; Turan, 2019; Y1lmaz \& Şahin, 2011). For example, in a study by Chai et al. (2010), which they carried out with pre-service teachers located in Singapore, it was concluded that the pre-service teachers possessed learning effort/process beliefs and that they had adopted a constructivist conception. It was reported that innate/fixed ability beliefs positively predicted the traditional conception, while learning effort/process beliefs positively predicted the constructivist conception. In addition, it was determined in the study that learning effort/process belief was a positive predictor of the constructivist learning-teaching conception. In another study in which similar results were obtained, Otting et al. (2010) showed that undergraduate students studying in different disciplines in the Netherlands had learning effort/process beliefs and had adopted a constructivist conception. In the study, it was reported that learning effort/process belief positively predicted the constructivist conception, whereas authority/expert knowledge and certainty of knowledge beliefs positively predicted the traditional conception. In a study by Tezci et al. (2016), which was conducted with Turkish preservice teachers attending different departments, it was found that the pre-service teachers generally believed that learning depends on effort and that they adopted a constructivist conception. In addition to these findings, it was reported that the belief that learning depends on effort had a predictive effect on the constructivist conception, while the belief that there is a single truth and that learning depends on ability had a predictive effect on the traditional conception. In contrast to this, Ketabi et al. (2014) revealed that pre-service teachers in the English department in Iran tended to adopt innate/fixed ability and certainty of knowledge beliefs, and that they were more inclined to adopt a traditional conception.

When the literature is examined, very few studies can be found that examine the extent of preservice physical education teachers' epistemological beliefs and teaching-learning conceptions, and the relationship between them. However, by determining pre-service physical education teachers' epistemological and pedagogical beliefs, a forecast can be made related to candidates' practices in the learning-teaching environment in their professional lives.

\subsection{The Aim}

The primary aim of this study was to identify pre-service teachers' epistemological and pedagogical beliefs and the relation between the beliefs. Another purpose of this study was to examine whether there is a relation between pre-service teachers' beliefs and their grades. 


\section{Method}

\subsection{Research Design}

The design of this research, which aims to determine pre-service physical education teachers' epistemological and pedagogical beliefs and the relationship between them, is a survey design and correlational design. Survey research aims to reveal the current views, beliefs, and attitudes of members of a known population (McMillan \& Schumacher, 2014). On the other hand, correlational studies, it is aimed to determine the relationship between two or more variables (Fraenkel et al., 2012).

\subsection{Participants}

Approval was obtained from the ethics committee on whether the research was scientifically and ethically appropriate. A total of 333 pre-service teachers studying in the Physical Education and Sports Teaching Departments at five different universities, which are located in the Aegean region of Turkey, during the 2018-2019 academic year participated in the research. Interviews were first held with faculty members employed at the universities selected for the implementation of the questionnaire study, and their permission was obtained for collecting the data at lesson times they considered suitable. Under the supervision of the lecturer responsible for the course, explanatory information was given by the researcher about the content and aim of the questionnaire study. Before the questionnaires were handed out, participants were informed that participation in the research was based on the principle of voluntariness and that personal information would be kept confidential, and the questionnaires were handed out to all students whose approval was obtained. No time limitation was set for the completion of the questionnaires. Incomplete forms and data containing extreme values were removed before beginning the analyses, and a total of 333 questionnaire forms were subjected to analysis. Frequencies and percentages related to the participants are shown in Table 1.

Table 1

Characteristics of the participants

\begin{tabular}{llcc}
\hline Variable & Group & $\mathrm{f}$ & $\%$ \\
\hline \multirow{2}{*}{ Grade } & First Grade & 163 & 48.9 \\
& Fourth Grade & 170 & 51.1 \\
\hline \multirow{2}{*}{ Gender } & Female & 141 & 42.3 \\
& Male & 192 & 57.7 \\
\hline \multirow{2}{*}{ Total } & & 333 & 100 \\
\hline
\end{tabular}

As can be seen in Table 1, 51.1\% $(n=170)$ of pre-service physical education teachers were in the fourth grade. In terms of gender, $57.7 \%(n=192)$ of the participants were male students.

\subsection{Data Collection Tools}

\subsubsection{Epistemological Beliefs Questionnaire}

For the examination of the pre-service physical education teachers' epistemological beliefs, the Epistemological Beliefs Questionnaire (Chan \& Elliott, 2002, 2004) adapted to Turkish by Aypay (2011b) was used. In order to reveal how the scale was perceived in Turkish culture, the researcher applied exploratory factor analysis on 341 pre-service teachers studying in different departments, and then, to examine the level of model fit, performed confirmatory factor analysis (Aypay, 2011b). Accordingly, as in the original scale, the scale was grouped in four factors, and the four factors explained $37.18 \%$ of the total variance. By considering the meaning contained in the items in the factors, the following names were given: Learning process-doubting authority/expert knowledge; innate/fixed ability; learning effort; and certainty of knowledge. In the form of the structure that emerged as a result of the exploratory factor analysis, the Epistemological Beliefs Questionnaire was subjected to confirmatory factor analysis and the level of fit was examined. The model fit data 
were determined as $\left[\chi^{2}=795.7, d f=399 p=.00\right], \chi^{2} / d f=1.99$, RMSEA=.05, CFI=.77, IFI=.78, and NFI=.65. The Cronbach alpha coefficients calculated for the four subdimensions of the scale were found to be $.77, .74, .59$ and .52 , respectively.

By reason the sample group of this study was different from both Chan \& Elliott's $(2002,2004)$ and Aypay's (2011b) research sample, construct validity was tested through confirmatory factor analysis. As a result of the factor analysis, Item 20 in the "learning process-doubting authority/expert knowledge" subdimension was removed since it had a factor loading below 0.30 and was not meaningful. In this study, the fit indices of the Epistemological Beliefs Questionnaire that were obtained as a result of the confirmatory factor analysis were determined as $\chi^{2} / d f=2.22$, RMSEA $=.061, \mathrm{GFI}=.85, \mathrm{CFI}=.85, \mathrm{IFI}=.86$, and $\mathrm{RMR}=.068$. Moreover, for this study, the Cronbach alpha values of the scale were found to be .72 for the general scale and $.65, .75, .62$ and .50 for the learning process-doubting authority/expert knowledge, innate/fixed ability, learning effort, and certainty of knowledge subdimensions, respectively.

High scores obtained from the subfactors indicate that the degree of belief represented by the relevant factor is high. Each belief dimension expresses a whole that is continuous between two extreme ends or poles. For example, while at one end of the "innate/fixed ability" subdimension, the belief exists that ability is innate and fixed, at the other end lies the belief that ability can change (Aypay, 2011b).

\subsubsection{Teaching-Learning Conceptions Questionnaire}

For examining the pre-service physical education teachers' pedagogical beliefs, the TeachingLearning Conceptions Questionnaire (Aypay, 2011a) was used. The Teaching-Learning Conceptions Questionnaire was developed by Chan and Elliott (2004) on 385 pre-service teachers in Hong Kong. The adaptation of the Teaching-Learning Conceptions Questionnaire to Turkish was carried out by Aypay (2011a). The validity and reliability study of the scale was conducted using the data obtained from 341 pre-service teachers. The data were subjected to confirmatory factor analysis, and the Cronbach alpha internal consistency coefficients and split-half correlation were examined. The fit indices of the model obtained in the factor analysis were examined, and it was seen that the chi-square value was $\left(\chi^{2}=1020.3, n=341, d f=404, p=.00\right)$. In the fit indices, the root mean square error value of (RMSEA=.067) was found to be within the acceptable limits. The NFI value was found to be .72, while the CFI value was found to be .80 . According to the results obtained, it was seen that the model had partial fit. As in the original scale, as a result of the factor analysis, 30 items were loaded on two factors, namely, constructivist conception and traditional conception. The reliability of the scale was measured with the Cronbach alpha coefficient and split-half methods. Reliability was found to be .71 for the general scale and .88 and .83 for the subdimensions. Correlation between split halves was found to be .77 (Aypay, 2011a).

To test the construct validity of the scale for this study, confirmatory factor analysis was carried out. As a result of the factor analysis, Items 10 and 27 in the traditional conception subdimension were removed since they had factor loadings below .30 and were not meaningful. The fit indices obtained from the confirmatory factor analysis were determined as $\chi^{2} / d f=2.79$, RMSEA=.074, $\mathrm{GFI}=.83, \mathrm{CFI}=.91, \mathrm{IFI}=.91$, and $\mathrm{RMR}=.084$. For this study, the Cronbach alpha values were calculated as .76 for the general scale and .84 and .78 for the traditional conception and constructivist conception subdimensions, respectively. Split-half reliability was revealed to be .77 . A high score obtained from the teaching-learning conceptions subdimensions indicates that the conception represented by the relevant subdimension has been adopted.

\subsection{Data Analysis}

The data obtained from the questionnaires were analysed using the SPSS 20 (Statistical Package for the Social Sciences) and LISREL 8.80 (Linear Structural Relations) software programs. To determine whether or not the assumptions related to univariate and multivariate statistical techniques were met, prior to the analysis, it was examined whether or not there were missing 
values in the data set, and it was determined that there were no missing values. Next, univariate and multivariate outliers were determined by means of Mahalanobis distance values, and seven data items were removed due to having extreme values. Furthermore, the univariate and multivariate normal distribution of the data set was examined. For the examination of univariate normal distribution, the skewness and kurtosis \pm 1.5 values (Tabachnick \& Fidell, 2013) were examined. In the examination of multivariate normal distribution, scatter diagrams (Çokluk et al., 2018) and Mardia's multivariate normality test (Bayram, 2016; Çelik \& Y1lmaz, 2016) were examined, and it was determined that the distribution did not deviate significantly from normality. Homogeneity of the distribution was examined with Levene's test, and it was found that the variance related to the groups was homogeneous. Moreover, to determine whether or not the data set had a multicollinearity problem, the paired correlations of the variables were examined and it was revealed that there was no correlation over $r>.90$.

In addition to the descriptive statistical analyses, independent samples t-test was utilised to determine whether or not there was a difference in pre-service teachers' views according to grade level. Also, to determine the relationship between the pre-service teachers' epistemological and pedagogical beliefs in the study, Pearson moments product correlation analysis was used. Correlation coefficients are evaluated as strong correlation between .70-1.00, moderate correlation between .70-.30, and weak correlation between .30-.00 (Büyüköztürk, 2018; Dancey \& Reidy, 2020). With regard to prediction of pedagogical beliefs by epistemological beliefs, path analysis was utilised. In the analyses that were determined, the level of significance was set at $p<.05$.

\section{Results}

In this section, findings related to the participants' epistemological and pedagogical beliefs are included with regard to the descriptive statistics, whether there was a difference in views depending on grade level, and the correlation between the subdimensions of both scales.

Table 2

Descriptive Statistics on Pre-Service Physical Education Teachers' Epistemological and Pedagogical Beliefs

\begin{tabular}{|c|c|c|c|c|c|}
\hline & Min. & Max. & $\mathrm{M} \pm \mathrm{SD}$ & Skewness & Kurtosis \\
\hline \multicolumn{6}{|c|}{ Epistemological Beliefs } \\
\hline LPDA/E & 2.80 & 5.00 & $3.96 \pm .40$ & .037 & -.167 \\
\hline $\mathrm{I} / \mathrm{FA}$ & 1.00 & 4.50 & $2.79 \pm .63$ & .033 & -.274 \\
\hline LE & 2.20 & 5.00 & $3.92 \pm .56$ & -.275 & .014 \\
\hline CK & 1.33 & 4.17 & $2.86 \pm .54$ & -.165 & -.160 \\
\hline \multicolumn{6}{|c|}{ Pedagogical Beliefs } \\
\hline TC & 1.19 & 4.44 & $2.99 \pm .62$ & -.228 & -.227 \\
\hline $\mathrm{CC}$ & 3.08 & 5.00 & $4.24 \pm .42$ & -.283 & -.394 \\
\hline
\end{tabular}

${ }^{*}$ Note. LPDA/E=Learning Process-Doubting Authority/Expert Knowledge; I/FA=Innate/Fixed Ability; LE=Learning Effort; $\mathrm{CK}=$ Certainty of Knowledge; $\mathrm{TC}=$ Traditional Conception; $\mathrm{CC}=$ Constructivist Conception

Examination of the findings included in Table 2 reveals that the pre-service teachers' mean scores for the learning process-doubting authority/expert knowledge $(M=3.96 \pm .40)$ and learning effort $(M=3.92 \pm .56)$ subdimensions are high, while their mean scores for the innate/fixed ability $(M=2.79 \pm .63)$ and certainty of knowledge $(M=2.86 \pm .54)$ subdimensions are moderate. In line with the findings obtained, it can be understood that the preservice physical education teachers generally accepted the propositions that "the learning process is important in learning and authority/expert knowledge should be questioned", and that "effort is important in learning", whereas they were generally undecided as to whether or not they agreed with the propositions that "learning ability is innate and does not change" and that "knowledge is certain and does not change". 
The results of the independent samples t-test, which was performed to determine whether or not the pre-service physical education teachers' epistemological and pedagogical beliefs differed according to the grade level variable, are presented in Table 3.

Table 3

Comparison of Pre-Service Physical Education Teachers' Epistemological and Pedagogical Beliefs According to Grade Variable

\begin{tabular}{lccrc}
\hline & $\begin{array}{c}\text { First Grade }(\mathrm{n}=163) \\
\mathrm{M} \pm \mathrm{SD}\end{array}$ & $\begin{array}{c}\text { Fourth Grade }(\mathrm{n}=170) \\
\mathrm{M} \pm \mathrm{SD}\end{array}$ & \multirow{2}{*}{ t(331) } & \multirow{2}{*}{$p$} \\
\hline Epistemological Beliefs & & & & \\
LPDA/E & $4.00 \pm .41$ & $3.92 \pm .39$ & 1.602 & .11 \\
I/FA & $2.75 \pm .62$ & $2.82 \pm .64$ & -1.112 & .26 \\
LE & $3.98 \pm .56$ & $3.87 \pm .55$ & 1.714 & .08 \\
CK & $2.85 \pm .54$ & $2.87 \pm .55$ & -.324 & .74 \\
\hline Pedagogical Beliefs & & & & \\
TC & $3.06 \pm .58$ & $2.92 \pm .65$ & 2.097 & .03 \\
CC & $4.28 \pm .40$ & $4.20 \pm .43$ & 1.640 & .10 \\
\hline
\end{tabular}

${ }^{*}$ Note. LPDA/E=Learning Process-Doubting Authority/Expert Knowledge; I/FA=Innate/Fixed Ability; LE=Learning Effort; $\mathrm{CK}=$ Certainty of Knowledge; $\mathrm{TC}=$ Traditional Conception; $\mathrm{CC}=$ Constructivist Conception

As can be seen in Table 3, when the pre-service physical education teachers' epistemological and pedagogical beliefs are examined according to their grade levels, it was determined that there is no significant difference in their mean scores for learning process-doubting authority/expert knowledge $[t(331)=1.602 ; p>.05]$; innate/fixed ability $[t(331)=-1.112 ; p>.05]$; learning effort $[t(331)=1.714 ; p>.05]$; certainty of knowledge $[t(331)=-.324 ; p>.05] ; \quad$ and constructivist conception $[t(331)=1.640 ; p>.05]$. On the other hand, a significant difference in mean scores for traditional conception was found in favour of first grade pre-service teachers $[t(331)=2.097 ; p<.05]$.

Table 4

The Relationship Between Pre-Service Physical Education Teachers' Epistemological and Pedagogical Beliefs

\begin{tabular}{lcccccc}
\hline \multicolumn{6}{l}{ Bivariate Correlations $(r)$} & \multicolumn{6}{l}{} \\
\hline & 1 & 2 & 3 & 4 & 5 & 6 \\
\hline LPDA/E & 1 & & & & & \\
I/FA & -.049 & 1 & & & & \\
LE & $.548^{* *}$ & -.059 & 1 & & & \\
CK & .053 & $.351^{* *}$ & $.140^{*}$ & 1 & 1 & \\
\hline TC & -.063 & $.409^{* *}$ & .015 & .501 & -.200 & 1 \\
CC & $.524^{* *}$ & $-.108^{*}$ & $.465^{* *}$ & -.079 & -.079
\end{tabular}

${ }^{*}$ Note. ${ }^{* *}$ Correlation is significant at .01 level. * Correlation is significant at .05 level. LPDA/E=Learning ProcessDoubting Authority/Expert Knowledge; I/FA=Innate/Fixed Ability; LE=Learning Effort; CK=Certainty of Knowledge; $\mathrm{TC}=$ Traditional Conception; $\mathrm{CC}=$ Constructivist Conception

The results in Table 4 show that, negative but insignificant correlation was found between traditional conception and learning process-doubting authority/expert knowledge belief $(r=-.063, p>.05)$, while a weak, positive but insignificant correlation was found between traditional conception and learning effort belief $(r=.015, p>.05)$. On the other hand, a moderate, significant positive correlation with traditional conception was revealed for innate/fixed ability belief $(r=.409, p<.01)$ and certainty of knowledge belief $(r=.501, p<.01)$. Moreover, a moderate, significant positive correlation with constructivist conception was found for learning process-doubting authority/expert knowledge belief $(r=.524, p<.01)$ and learning effort belief $(r=.465, p<.01)$, while a weak, significant negative correlation between constructivist conception and innate/fixed ability belief was determined $(r=-.108, p<.05)$. On the other hand, a weak, 
negative but insignificant correlation was revealed between constructivist conception and certainty of knowledge belief $(r=-.079, p>.05)$.

Figure 1

The hypothetical model of structural relations between the epistemological beliefs and the pedagogical beliefs

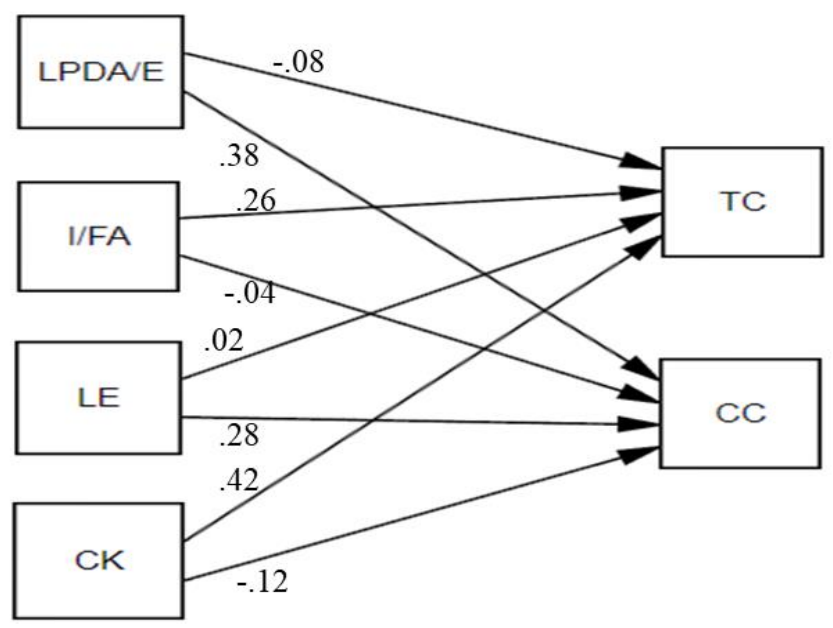

Chi-square $=5.85, \quad \mathrm{df}=1, \quad \mathrm{P}$-value $=.015, \quad \mathrm{RMSEA}=.122$

As can be seen in Figure 1, path analysis was performed to examine the extent to which the preservice physical education teachers' epistemological beliefs predicted their pedagogical beliefs. In the model that was created based on the theoretical model, the subdimensions of both scales were defined as observed variables in the LISREL software program. The learning process-doubting authority/expert knowledge, innate/fixed ability, learning effort and certainty of knowledge subdimensions of epistemological beliefs were included in the model as independent variables (exogenous variables), while traditional conception and constructivist conception, which constitute the subdimensions of pedagogical beliefs, were included in the model as dependent variables (endogenous variables). According to the hypothetical path analysis model, it was determined that some fit index values of the tested model were not within the acceptable intervals $\left(\chi^{2} / d f=5.85\right.$, $p<.05$, RMSEA =.122). Therefore, the analyses were continued by making certain changes to the model, and an alternative model between variables having significant path coefficients was created (Figure 2).

\section{Figure 2}

The alternative model of structural relations between the epistemological beliefs and the pedagogical beliefs

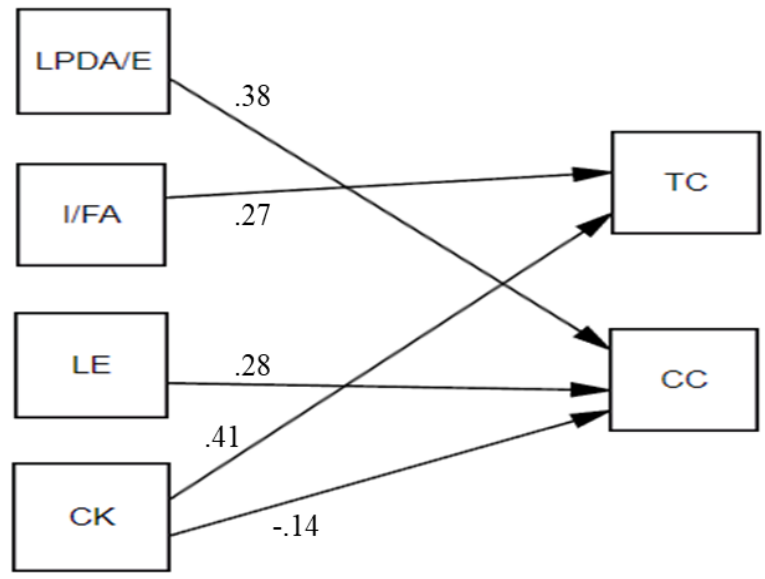

Chi-square $=8.53, \quad \mathrm{df}=4, \quad \mathrm{P}$-value $=.073, \quad \mathrm{RMSEA}=.059$ 
Figure 2 shows that innate/fixed ability belief $(\beta=.27, t=5.49)$ and certainty of knowledge belief $(\beta=.41, t=8.51)$ are moderate, positive predictors of traditional conception $(p<.01)$. According to these findings, $32 \%$ of the total variance in the traditional conception variable is explained by innate/fixed ability belief and certainty of knowledge belief. On the other hand, it was determined that learning process-doubting authority/expert knowledge belief ( $\beta=.38, t=7.04)$ and learning effort belief $(\beta=.28, t=5.16)$ are moderate, positive predictors of constructivist conception $(p<.01)$, while certainty of knowledge belief is a weak-moderate negative predictor of constructivist conception $(\beta=-.14, t=-3.05 ; p<.01)$. According to these findings, $34 \%$ of the total variance in the constructivist conception variable is explained by learning process-doubting authority/expert knowledge belief, learning effort belief, and certainty of knowledge belief. Finally, path analysis results and the goodness-of-fit values for the final model are presented in Table 5 and Table 6 respectively.

Table 5

Path analysis results

\begin{tabular}{llccc}
\hline Path & & & & \\
\cline { 1 - 2 } From & To & Path Coefficient & $t$ & $p$ \\
\hline LPDA/E & CC & .38 & 7.04 & $<.01$ \\
I/FA & TC & .27 & 5.49 & $<.01$ \\
LE & CC & .28 & 5.16 & $<.01$ \\
CK & TC & .41 & 8.51 & $<.01$ \\
CK & CC & -.14 & -3.05 & $<.01$
\end{tabular}

${ }^{*}$ Note. LPDA/E=Learning Process-Doubting Authority/Expert Knowledge; I/FA=Innate/Fixed Ability; LE=Learning Effort; CK = Certainty of Knowledge; TC=Traditional Conception; CC=Constructivist Conception

According to the results presented in Table 5, all the path coefficients were found to be statistically significant $(L P D A / E \rightarrow C C, \beta=.38 ; I / F A \rightarrow T C, \beta=.27 ; L E \rightarrow C C, \beta=.28 ; C K \rightarrow T C$, $\beta=.41 ; C K \rightarrow C C, \beta=-.14)$.

Table 6

Fit Index Values Regarding the Alternative Model

\begin{tabular}{lccc}
\hline Fit Measure & Acceptable Fit & Good Fit & Research Value \\
\hline$\chi^{2} / d f$ & $2 \leq \chi^{2} / d f \leq 5$ & $0 \leq \chi^{2} / d f \leq 2$ & 2.20 (Acceptable Fit) \\
RMSEA & $.05 \leq R M S E A \leq .08$ & $.00 \leq R M S E A \leq .05$ & .059 (Acceptable Fit) \\
GFI & $.90 \leq G F I \leq .95$ & $.95<G F I \leq 1.00$ & .99 (Good Fit) \\
AGFI & $.85 \leq A G F I \leq .90$ & $.90<A G F I \leq 1.00$ & .96 (Good Fit) \\
NFI & $.90 \leq N F I \leq .95$ & $.95<N F I \leq 1.00$ & .98 (Good Fit) \\
NNFI & $.90 \leq N N F I \leq .95$ & $.95<N N F I \leq 1.00$ & .96 (Good Fit) \\
IFI & $.90 \leq I F I \leq .95$ & $.95<I F I \leq 1.00$ & .99 (Good Fit) \\
CFI & $.95 \leq C F I \leq .97$ & $.97<C F I \leq 1.00$ & .99 (Good Fit) \\
RMR & $.05 \leq R M R \leq .08$ & $.00 \leq R M R \leq .05$ & .00 (Good Fit) \\
SRMR & $.05 \leq S R M R \leq .08$ & $.00 \leq S R M R \leq .05$ & .03 (Good Fit) \\
\hline
\end{tabular}

${ }^{*}$ Note. For the recommended values, please see Bayram (2016), Çelik and Yılmaz (2017), Çokluk et al. (2018) Meydan and Şeşen (2015) and Seçer (2017).

As can be seen in Table 6, as a result of the path analysis that was carried out, it was determined that all the goodness-of-fit values of the tested model are within good fit and acceptable fit intervals. Therefore, these findings reveal that the alternative model that was created fits the data.

\section{Discussion}

The results of the current paper revealed that the pre-service physical education teachers were inclined to believe in the importance of effort and process in learning and in the need to question expert/authority knowledge, whereas they were undecided as to whether to believe that learning 
ability is innate and fixed, and in the certainty of knowledge. Similarly, in Abakay's (2013) study conducted with final-year pre-service physical education teachers attending a university in Turkey, it was determined that more students believed that knowledge is relative than those who believed that knowledge is accurate, and that more students believed that effort and process are important in learning compared to those who believed that learning depends on ability. In another study, Canpolat (2016) with pre-service physical education teachers in five universities located in various regions of Turkey uncovered that the teacher candidates held sophisticated beliefs that learning depends on effort rather than on ability. On the other hand, in a study carried out by Özkatar-Kaya (2018) with pre-service physical education teachers studying in first and fourth grades in universities located in the Anatolian region of Turkey, it was reported that scores obtained from the subdimensions of epistemological beliefs were close to average values. In a study conducted with pre-service physical education teachers attending 14 universities in seven different geographical regions of Turkey, Alemdağ (2015), while stating that the scores obtained by the participants from the subdimensions of epistemological beliefs were at a medium level, also reported that their beliefs that learning is dependent on effort and that learning is dependent on ability were not developed, whereas their beliefs that there is a single truth were developed. The difference in the obtained findings may be due to the fact that the study universe was limited to universities located only in the Aegean region and that participants were mostly individuals living in the Aegean region.

In terms of pedagogical beliefs, it can be understood that the pre-service physical education teachers had vigorously adopted a constructivist conception, whereas they were undecided as to whether or not they had adopted a traditional conception. In Turkey since 2005, a student-centred constructivist approach has been taken as the basis in teaching programmes rather than a teachercentred behaviourist approach. Therefore, it is desired and important that pre-service teachers, who will have an important role in the successful implementation of curricula and achieving the specified objectives in the curriculum in their future professional lives, should adopt the conception required in the curriculum. On the other hand, an issue that should be highlighted is the fact that the pre-service physical education teachers had not completely rejected the traditional conception, that is, they were undecided. A likely reason for this may be certain statements included in the traditional conception factor. For example, the statement, "Teachers must always have control over the things their students do", which is found in Item 12 of the traditional conception factor, emerged as one of the statements that resulted in an increase in the factor mean value. Some statements in the traditional conception subdimension may have led to analogy being made with the command style in physical education instruction. One of the effective parameters in preferring the command style, and perhaps the most important one, is the elimination of a series of risks specific to the sports branch-activity, and the provision of safety measures for preventing sports accidents. When evaluated in this framework, sports such as parachute jumping, canoeing, swimming or diving instruction, and mountain hiking and climbing, by their nature involve a number of risk factors. For this reason, the pre-service physical education teachers may have considered the potential risks of sport and considered it necessary to be in control in an activity environment.

When the literature is examined, in the studies conducted by Abakay (2013) with final-year preservice physical education teachers and Turan (2019) with sports science faculty students, it was revealed that students adopted a constructivist conception more than a traditional conception. Again, in studies carried out with pre-service teachers in different disciplines in Turkey, it is seen that students adopted a constructivist conception (e.g. Aypay, 2011a; Aydin et al., 2015; Can \& Çelik, 2018). It is thought that the similar results obtained in this research and other studies may be due to the reforms based on the constructivist conception in the preparation of teaching programmes and in education practices in the Turkish Education System from 2005 onwards. When studies conducted overseas are examined, in the study made by Chan and Elliott (2004) with pre-service teachers in Hong Kong, it was concluded that the students had not clearly adopted 
either a traditional or a constructivist conception. The researchers associated these findings with the fact that until a short time before, a traditional teaching and learning conception (the effect of the Philosophy of Confucianism) had been implemented in Hong Kong (Aypay 2011a). In a more recent study by Cheng et al. (2009), it was revealed that pre-service teachers in Hong Kong had mostly adopted a constructivist conception. In studies made by Chai and Khine (2008) and Chai et al. $(2009,2010)$ with pre-service teachers in Singapore, which has various ethnicities, and by Otting et al. (2010) with pre-service teachers in the Netherlands, it was found that pre-service teachers had primarily adopted a constructivist conception. However, in the study conducted by Ketabi et al. (2014) with pre-service teachers in the English department in Iran, it was stated that students had mostly adopted a traditional conception, and that the reason for this was the fact that modernist philosophical thought was dominant in English teaching in Iran. In the light of all these findings, it can be said that the culture in which one lives, the education system that has been recently adopted and is still implemented, and the discipline that is studied are effective in the adoption of teaching and learning conceptions.

A significant difference was not found in the pre-service physical education teachers' epistemological beliefs according to their grade levels. When the literature is examined, studies are mostly found in which students acquire more sophisticated epistemological beliefs as their grade level increases (e.g., Aypay, 2011b; Erdamar \& Alpan, 2015; Rodriguez \& Cano, 2007; Schommer, 1993, 1998; Şekercioğlu \& Yıldırır, 2018). Additionally, there are also studies in which grade level has no effect on epistemological beliefs (Güngör, 2016; Koç \& Memduhoğlu, 2017; Kutluca et al., 2018). It can be expected that as students' grade level increases at university, they will believe that effort and process are important in learning rather than ability, and that knowledge can change according to its context and will have a relative structure rather than a certain and unchangeable structure. However, a factor that should be highlighted is that the first and final grade students in this study comprise different individuals. Therefore, the previous educational experiences of the students who participated in the research were different from each other. Considered from this viewpoint, in order to obtain more valid and reliable results, it is necessary to conduct longitudinal studies with the same individuals.

When the pre-service physical education teachers' pedagogical beliefs were examined according to their grade level it was revealed that first grade pre-service teachers had adopted a traditional conception more than fourth grade pre-service teachers. However, no significant difference was found in their views in terms of the constructivist conception. The reason why final-year students had adopted a traditional conception less than first-year students may be that they had made gains in pedagogical terms as a result of knowledge accumulated in courses such as special teaching methods, teaching principles and methods, measurement and evaluation, classroom management, and educational games. In Aypay's (2011a) study conducted with undergraduate education faculty students and master's students in a programme without thesis at a social sciences institute, a significant decrease was observed in students' tendency to adopt a traditional conception as grade level increased. In a study by Yllmaz and Şahin (2011) carried out with pre-service teachers studying in different departments, it was reported that first grade students adopted a traditional conception more than students in other grades, whereas students in third grade adopted a constructivist conception more than students in other grades. In a study conducted by Aydin et al. (2015) with pre-service science teachers, too, a significant decrease was seen in students' tendency to adopt a traditional conception as grade level increased, while a significant increase in their tendency to adopt a constructivist conception was observed. When the results of the conducted studies are evaluated in general, it can be said that the increase in pre-service teachers' learning experiences increased their tendency to adopt a constructivist conception while it decreased their inclination to adopt a traditional conception. This finding can be interpreted to say that the traditional conception may still be ongoing in lower levels of the Turkish Education System such as secondary school and high school. 
The relationship between the pre-service physical education teachers' epistemological and pedagogical beliefs showed a weak, negative but insignificant correlation between traditional conception and learning process-doubting authority/expert knowledge belief, while a weak, positive but insignificant correlation was found between traditional conception and learning effort belief. In addition, a moderate, significant positive correlation with traditional conception was revealed for innate/fixed ability belief and certainty of knowledge belief. According to these results, as the pre-service physical education teachers' belief that ability is innate and fixed, and that knowledge is certain and unchangeable increased, their tendency to adopt a traditional conception in teaching and learning also increased. Similar results can also be found in the studies by Aypay (2011a) and Ketabi et al. (2014). However, different from this study, in her study, Aypay (2011a) revealed a significant, positive relationship between the learning process-doubting authority/expert knowledge subdimension and the traditional conception, albeit at a low level. In this study, a positive relationship, albeit insignificant, was also found between the belief that effort is important in learning and traditional conception. In the studies made by Chan and Elliott (2004) and Otting et al. (2010), a positive relationship of belief that learning ability is innate/fixed, belief in authority/expert knowledge, and belief in the certainty of knowledge with traditional conception was found. In the study carried out by Yilmaz and Şahin (2011), a positive correlation of belief that "there is only one truth", a negative correlation of belief that "intelligence is multifaceted", and a weak, positive correlation of belief that "learning depends on effort" with traditional conception were found.

As another result, a moderate, significant positive correlation with constructivist conception was found for learning process-doubting authority/expert knowledge belief and learning effort belief, while a weak, significant negative correlation between constructivist conception and innate/fixed ability belief was determined. Furthermore, a weak, negative but insignificant correlation was revealed between constructivist conception and certainty of knowledge belief. According to these findings, as pre-service physical education teachers' beliefs in the importance of process in learning, in questioning authority knowledge and in the importance of effort in learning increased, their tendency to adopt a constructivist conception in teaching and learning also increased. However, as their belief that ability in learning is innate and fixed increased, their tendency to adopt a constructivist conception decreased. In the study by Tezci et al. (2016), a negative correlation with constructivist conception was found for belief that learning depends on ability and that there is only one truth, while a positive correlation was found between belief that learning depends on effort and constructivist conception. In the study made by Abakay (2013), a positive relationship with constructivist conception was determined for belief that knowledge is relative and that learning depends on effort. In the study by Chan and Elliott (2004), a negative relationship with constructivist conception was found for belief that effort and process are important in learning. The researchers interpreted this result as contradictory, and suggested that the students' may have perceived the belief that "effort and process are important in learning" as "doing plenty of repetition" in order to acquire knowledge (Chai et al., 2010). Furthermore, the students who made up the study group revealed that despite having sophisticated epistemological beliefs, they did not show a tendency towards a constructivist conception in terms of the teaching practice they had adopted.

In terms of prediction of the pre-service physical education teachers' pedagogical beliefs by their epistemological beliefs, it was determined that learning process-doubting authority/expert knowledge belief and learning effort belief were positive predictors of constructivist conception, while they did not have significant effects on traditional conception. According to this finding, it can be said that pre-service physical education teachers who believed that effort and the understanding process are important in learning and that authority knowledge should be questioned were more inclined to adopt a constructivist conception. A constructivist approach directs students towards investigation. It takes creativity, critical thinking, activeness and analysis as the basis and supports learning together. It stresses the necessity to enable the acquisition of 
new ideas and understanding as a result of students' own experiences (Akınoğlu, 2018). In the constructivism process, the individual tries to create meaning related to new knowledge (Şişman, 2018). The learning individual is not a passive recipient of external stimulants, but an assimilator of these and an active creator of behaviour. In other words, the individual must make an effort for learning (Erden, 2017). Therefore, considering the content of the belief that process and effort are important in learning, it can be understood that it is closely correlated with the constructivist conception. When the literature is examined, studies can be found that reveal that belief in the learning process/effort positively predicts the constructivist approach, while they negatively predict the traditional approach (Chai et al., 2010; Otting et al., 2010; Tezci et al., 2016). On the other hand, it was revealed in the study by Chan and Elliot (2004) that belief in the learning process/effort negatively predicted the constructivist approach.

In this study, it was found that belief in innate/fixed ability positively predicted the traditional approach, while no significant effect on the constructivist approach was found. According to this result, it can be stated that pre-service physical education teachers who believed that learning ability is innate and cannot be changed were more inclined to adopt a traditional approach in teaching and learning. According to Özerbaş (2012), a traditional teacher-centred approach that supports competition does not increase students' motivation, while it also prevents students from using their potential due to the apprehension it creates. According to Ekiz (2006), in the traditionalbehaviourist approach, it is expected that every study will acquire similar knowledge, skills and understanding as a result of the instruction that is given. In the light of this information, the past and present learning experiences of the pre-service teachers comprising the study group can be given as a reason why their belief that learning is dependent on ability and cannot be changed was associated with the traditional approach. These findings are similar to the results of the research carried out by Chan and Elliot (2004), Chai et al. (2010) and Otting et al. (2010). Moreover, in the study by Tezci at al. (2016), it was concluded that the belief that learning depends on ability positively predicted traditional conception, while it negatively predicted constructivist conception.

Another result of the research was that belief in the certainty of knowledge was a positive predictor of traditional conception, while it was a negative predictor of constructivist conception. According to this finding, it can be said that pre-service physical education teachers who believed that knowledge is certain and unchangeable were more inclined to adopt a traditional conception of teaching and learning. According to Özden (2013), in the traditional conception, scientific facts are single and absolute, and cannot be debated. Those who adopt this understanding believe in the absoluteness of scientific knowledge, since they are disposed to believe that the final point reached in science is the final point that mankind can reach. According to Şişman (2018), however, the current educational approach emphasises the pluralist structure of truth, the irrational and cultural aspect of humans, alternative types of knowledge and methods of knowledge acquisition, and the changeability and relativity of scientific facts. Therefore, considering the content of the belief in the certainty of knowledge, it can be understood that it is associated with the traditional conception. Similarly, in the conducted studies (Chai et al., 2010; Chan \& Elliott, 2004; Otting et al., 2010; Tezci et al., 2016), while it was concluded that belief in the certainty of knowledge positively predicts traditional conception, no finding can be encountered to the effect that it negatively predicts constructivist conception. This result that was made in the study differs from the results of previous studies.

\section{Conclusion}

Results from this study about the pre-service physical education teachers' epistemological and pedagogical beliefs was that most of them believed that learning effort and process was more important than innate ability. Moreover, another result was that most of the pre-service teachers believed that knowledge changes. Regarding the pedagogical beliefs, teacher candidates were found to have much stronger leanings towards the constructivist conception of teaching-learning. 
While a significant difference was not found in the pre-service physical education teachers' epistemological beliefs according to their grade levels, it was revealed that first-grade pre-service teachers had adopted a traditional conception more than fourth-grade pre-service teachers. However, no significant difference was found in their views in terms of the constructivist conception. Although the research presents partial information related to similarities and differences in beliefs of first grade students who have just begun their university education and final grade students who are about to start their profession, longitudinal studies should be conducted with the same participants in order to obtain more valid and reliable results.

In this study, a moderate, significant positive correlation with traditional conception was revealed for innate/fixed ability belief and certainty of knowledge belief. Moreover, a moderate, significant positive correlation with constructivist conception was found for learning processdoubting authority/expert knowledge belief and learning effort belief, while a weak, significant negative correlation between constructivist conception and innate/fixed ability belief was determined.

As a result of path analysis was found that innate/fixed ability belief and certainty of knowledge belief are moderate, positive predictors of traditional conception. On the other hand, it was determined that learning process-doubting authority/expert knowledge belief and learning effort belief are moderate, positive predictors of constructivist conception, while certainty of knowledge belief is a weak-moderate negative predictor of constructivist conception. In summary, in the light of the findings obtained from this study, it can be said that pre-service teachers who believe in the importance of effort and process in learning will adopt the constructivist conception more, on the other hand, pre-service teachers who believe that learning ability is innate/fixed, and knowledge is certain will tend to adopt the traditional understanding more.

The study was carried out with students studying in the Physical Education and Sports Teaching Department at five universities located in the Aegean region of Turkey. Therefore, future studies can be designed in such a way as to include universities located in different regions. Another limitation of this study was that the study group consisted of pre-service physical education teachers. In future research, the epistemological beliefs and pedagogical beliefs of preservice teachers can be examined more comprehensively by including different departments in the study group.

The effect of instructional practices and approaches on students' epistemological and pedagogical beliefs is clear. Therefore, changes in pre-service teachers' beliefs can be examined with pretest-posttest experimental studies in which alternative instructional approaches are implemented. Finally, with the aim of determining the effect of pre-service physical education teachers' epistemological and pedagogical beliefs on certain parameters such as the teaching strategies and methods that they use, their ways of preparing lesson plans, the teaching materials that they use and their ways of communication with their students, their micro-teaching practices can be observed in physical education and sports teaching and teaching practice courses.

Acknowledgements. This research is based on the master's thesis of the first author. The research was also presented as an oral presentation at the 4th International Eurasian Conference Sport Education and Society held at Pamukkale University on 6-8 December 2019.

\section{References}

Abakay, U. (2013). Investigating physical education teacher candidates' epistemological beliefs. Life Science Journal, 10(3), 2658-2664.

Akınoğlu, O. (2018). Öğrenme-öğretmede yeni yönelimler [New directions in learning-teaching]. In B. Oral (Ed.), Öğrenme öğretme kuram ve yaklaşımları [Learning teaching theories and approaches] (4th ed.). Pegem Akademi.

Akyıldız, S. (2016). Investigating novice teachers' teaching-learning approaches on the basis of adoption of curriculum and application variables. Journal of Bayburt Education Faculty, 11(1), 239-252.

Akyıldız, S. (2018). Relationships between epistemological beliefs and teaching-learning approaches of high school teachers. The Journal of National Education, 47(217), 77-96. 
Alemdağ, C. (2015). Pre-service physical education teachers' epistemological beliefs, academic self-efficacy and learning approaches (Unpublished doctoral dissertation). Karadeniz Technical University, Trabzon, Turkey.

Aydın, Ö., Tunca, N., \& Alkın-Şahin, S. (2015). Investigation of pre-service science teachers' conceptions of teaching and learning in relation to some variables. Kastamonu Education Journal, 23(3), 1331-1346.

Aypay, A. (2011a). The adaptation of the teaching-learning conceptions questionnaire and its relationships with epistemological beliefs. Educational Sciences: Theory \& Practice, 11(1), 7-29.

Aypay, A. (2011b). Adaptation of epistemological beliefs questionnaire in Turkish and investigation of preservice teachers' beliefs. Eskişehir Osmangazi University Journal of Social Sciences, 12(1), 1-15.

Bahçıvan, E. (2017). Epistemological research in educational sciences: Critical investigation of past, present and future perspectives. Mersin University Journal of the Faculty of Education, 13(2), 760-772. https:// doi.org/10.17860/mersinefd.301121

Baş, G., \& Beyhan, Ö. (2013). Correlation between pre-service teachers' teaching-learning conceptions and their student control ideologies. H. U. Journal of Education, Spesical Issue(1), 14-26. https:/ /hdl.handle.net/20.500.12452/2007

Bayram, N. (2016). Yapısal Eşitlik Modellemesine Giriş Amos Uygulamaları [Introduction to Structural Equation Modeling Amos Applications] (3rd ed.). Ezgi Kitabevi.

Brunning, R. H., Schraw, G. J., Norby, M. M., \& Ronning, R. R. (2004). Cognitive Psychology and Instruction. Merril Prentice Hall.

Büyüköztürk, Ş. (2018). Sosyal Bilimler için Veri Analizi El Kitabı [Guidebook of data analysis for social sciences] (24th ed.). Pegem Akademi. https:// doi.org/10.14527/9789756802748

Can, Ş., \& Çelik, C. (2018). Investigation of science and classroom teachers' teaching learning understandings. Afyon Kocatepe University Journal of Social Sciences, 20(1), 327-339.

Canpolat, A. M. (2016). The prediction of physical education teacher candidates' achievement goals regarding their learning and studying approaches and epistemological beliefs. International Online Journal of Educational Sciences, 8(2), 83-92.

Cevizci, A. (2018). Eğitim Felsefesi [Philosophy of Education] (6th ed.). Say Yayınları.

Chai, C. S., \& Khine, M. S. (2008). Assessing The Epistemological and Pedagogical Beliefs among Pre-Service Teachers in Singapore. In M. S. Khine (Ed.), Knowing, Knowledge and Beliefs: Epistemological Studies across Diverse Cultures (pp. 287-302). Springer. https://doi.org/10.1007/978-1-4020-6596-5

Chai, C. S., Teo, T., \& Lee, C. B. (2010). Modelling the relationship among beliefs about learning, knowledge, and teaching of pre-service teachers in Singapore. The Asia-Pacific Education Researcher, 19(1), 25-42.

Chai, C. S., Teo, T., \& Lee, C. B. (2009). The change in epistemological beliefs and beliefs about teaching and learning: A study among pre-service teachers. Asia-Pacific Journal of Teacher Education, 37(4), 351-362. https://doi.org/10.1080/13598660903250381

Chan, K. W., \& Elliott, R. G. (2002). Exploratory study of Hong Kong teacher education students' epistemological beliefs: Cultural perspectives and implications on beliefs research. Contemporary Educational Psychology, 27(3), 392-414. https://doi.org/10.1006/ceps.2001.1102

Chan, K. W., \& Elliott, R. G. (2004). Relational analysis of personel epistemology and conceptions about teaching and learning. Teaching and Teacher Education, 20(8), 817-831. https://doi.org/10.1016/j.tate.2004.09.002

Cheng, M. M., Chan, K. W., Tang, S. Y., \& Cheng, A. Y. (2009). Pre-service teacher education students' epistemological beliefs and conceptions of teaching. Teacher and Teacher Education, 25(2), 319-327. https://doi.org/10.1016/j.tate.2008.09.018

Çelik, H. E., \& Yılmaz, V. (2016). Lisrel 9.1 ile Yapısal Eşitlik Modellemesi Temel Kavramlar-UygulamalarProgramlama [Structural Equation Modeling with Lisrel 9.1 Basic Concepts-Applications-Programming] (3rd ed.). Anı Yayıncilik.

Çokluk, Ö., Şekercioğlu, G., \& Büyüköztürk, Ş. (2018). Sosyal Bilimler için Çok Değişkenli İstatistik SPSS ve LISREL Uygulamalarn [Multivariate Statistics SPSS and LISREL Applications for Social Sciences] (5th ed.). Pegem Akademi.

Dancey, C. P., \& Reidy, J. (2020). Statistics without Maths for Psychology (8th ed.). Pearson.

Deryakulu, D. (2017). Epistemolojik İnançlar [Epistemological Beliefs]. In Y. Kuzgun, D. Deryakulu (Eds.), Eğitimde Bireysel Farklılıklar [Individual Differences in Education] (4th ed.). Nobel.

Dimov, B. C., Atanasoska, T., Iliev, D., Andonovska-Trajkovska, D., \& Seweryn-Kuzmanovska, M. (2015). Importance of investment in research's of students and teachers epistemological and pedagogical beliefs. Procedia-Social and Behavioral Sciences, 191, 1299-1303. https://doi.org/10.1016/j.sbspro.2015.04.582 
Ekiz, D. (2006). Öğretmen Eğitimi ve Öğretimde Yaklaşımlar [Teacher Education and Teaching Approaches]. Nobel.

Erdamar, G., \& Alpan, G. (2015). Öğretmen adaylarının epistemolojik inançlarının ve problem çözme yeteneklerinin gelişimi: Boylamsal bir çalışma [The development of pre-service teachers' epistemological beliefs and problem solving skills: A longitudinal study]. The Journal of Turkish Educational Sciences, 13(2), 77-91.

Erden, M. (2017). Eğitim bilimlerine giriş [Introduction to educational sciences] (11th ed.). Arkadaş Yayınevi.

Fraenkel, J.R., Wallend, N.E., \& Hyun, H.H. (2012). How to design and evaluate research in education (8th ed). McGraw Hill.

Güngör, N. B. (2016). The survey of relation between epistemological beliefs and leadership qualities of physical education teacher candidates (Unpublished master's thesis). Gazi University, Ankara, Turkey.

Hofer, B. K. (2002). Personel Epistemology as a Psychological and Educational Construct: An Introduction. In B. K. Hofer, P. R. Pintrich (Eds.), Personel Epistemology: The Psychology of Beliefs about Knowledge and Knowing (pp. 3-15). Mahwah, NJ: Erlbaum.

Hofer, B. K., \& Pintrich, P. R. (1997). The development of epistemological theories: Beliefs about knowledge and knowing and their relation to learning. Review of Educational Research, 67(1), 88-140. https://doi.org/10.3102/00346543067001088

Kang, N. H., \& Wallace, C. S. (2005). Secondary science teachers' use of laboratory activities: Linking epistemological beliefs, goals, and practices. Science Teacher Education, 89(1), 140-165. https://doi.org/10.1002/sce.20013

Ketabi, S., Zahibi, R., \& Ghadiri, M. (2014). Pre-service english teachers' epistemological beliefs and their conceptions of teaching. International Journal of Research Studies in Psychology, 3(1), 3-12. https://doi.org/10.5861/ijrsp.2013.398

Koç, S., \& Memduhoğlu, H. B. (2017). Epistemological beliefs of preservice teachers: A mixed method study. Electronic Journal of Social Sciences, 16(60), 119-134. https:// doi.org/10.17755/esosder.289655

Köse, S., \& Dinç, S. (2012). The relationships among pre-service science and technology teachers' biology self-efficacy perceptions and epistemological beliefs. Mustafa Kemal University Journal of Social Sciences Institute, 9(18), 121-141.

Kutluca, A.Y., Soysal, Y., \& Radmard, S. (2018). Reliability and applied adaptation study of the epistemological belief scale towards learning. Journal of Theory and Practice in Education, 14(1), 1-31.

McMillan, J. W., \& Schumacher, S. (2014). Research in education: Evidence-based inquiry (7. bs.). Pearson.

Meydan C. H., \& Şeşen H. (2015). Yapısal Eşitlik Modellemesi Amos Uygulamalan [Structural Equation Modeling Amos Applications] (2. Basım). Detay.

Otting, H., Zwaal, W., Tempelaar, D., \& Gijselaers, W. (2010). The structural relationship between students' epistemological beliefs and conceptions of teaching and learning. Studies in Higher Education, 35(7), 741760. https:// doi.org/10.1080/03075070903383203

Özden, Y. (2013). Eğitimde Yeni Değerler [New Values in Education] (9th ed.). Pegem Akademi.

Özden, Y. (2014). Öğrenme ve Öğretme [Learning and Teaching] (12th ed.). Pegem Akademi.

Özerbaş, M. A. (2012). Bağlaşık Öğrenme Kuramı [Anchored Learning Theory]. In Z. Kaya (Ed.), Öğrenme ve Öğretme Kuramlar, Yaklaşımlar, Modeller [Learning and Teaching Theories, Approaches, Models]. Pegem Akademi.

Özkatar-Kaya, E. (2018). Investigation of the relationship of the epistemological beliefs, self-regulation and selfefficacy levels of physical education and sport teacher candidates (Unpublished doctoral dissertation). Erciyes University, Kayseri, Turkey.

Rodriguez, L. \& Cano, F. (2007). The learning approaches and epistemological beliefs of university students: A cross-sectional and longitudinal study. Studies in Higher Education, 32(5), 647-667. https://doi.org/10.1080/03075070701573807

Schommer, M. (1990). Effects of beliefs about the nature of knowledge on comprehension. Journal of Educational Psychology, 82(3), 498-504. https://doi.org/10.1037/0022-0663.82.3.498

Schommer, M. (1993). Epistemological development and academic performance among secondary school students. Journal of Educational Psychology, 85(3), 406-411.

Schommer, M. (1994). Synthesizing epistemological belief research: Tentative understandings and provocative confusions. Educational Psychology Review, 6(4), 293-319. https://doi.org/10.1007/BF02213418

Schommer, M. (1998). The influence of age and schooling on epistemological beliefs. The British Journal of Educational Psychology, 68, 551-562. https://doi.org/10.1111/j.2044-8279.1998.tb01311.x 
Schommer-Aikins, M. (2002). An Evolving Theoretical Framework for An Epistemological Belief System. In B. K. Hofer, P. R. Pintrich (Eds.) Personel Epistemology: The Psychology of Beliefs about Knowledge and Knowing (pp. 103-118). Erlbaum.

Schraw, G., \& Olafson, L. (2003). Teachers' epistemological world views and educational practices. Journal of Cognitive Education and Psychology, 3(2), 178-235. https://doi.org/10.1891/194589503787383109

Seçer, İ. (2017). SPSS ve LISREL ile Pratik Veri Analizi Analiz ve Raporlaştırma [Practical Data Analysis Analysis and Reporting with SPSS and LISREL] (3rd. Ed.). Anı Yayincilik.

Sinatra, G. M., \& Kardash, C. M. (2004). Teacher candidates' epistemological beliefs, dispositions, and views on teaching as persuasion. Contemporary Educational Psychology, 29(4), 483-498. https:// doi.org/10.1016/j.cedpsych.2004.03.001

Şekercioğlu, A. G., \& Yıldırır, H. E. (2018). Examination of the epistemological beliefs of the teacher candidates according to some variables. Necatibey Faculty of Education Electronic Journal of Science and Mathematics Education, 12(1), 205-227. https:// doi.org/10.17522/balikesirnef.437742

Şişman, M. (2018). Eğitime Giriş [Introduction to Education] (18th ed.). Pegem.

Tabachnick, B. G., \& Fidell, L. S. (2013). Using Multivariate Statistics (6th ed.). Pearson.

Teo, T., Chai, S. C., Hung, D., \& Lee, C. B. (2008). Beliefs about teaching and uses of technology among preservice teachers. Asia-Pacific Journal of Teacher Education, 36(2), 163-174. https://doi.org/10.1080/13598660801971641

Tezci, E., Erdener, M. A., \& Atıc1, S. (2016). The effect of pre-service teachers' epistemological beliefs on teaching approaches. Universal Journal of Educational Research, 4(n12A), 205-215. https://doi.org/10.13189/ujer.2016.041326

Tsai, C. C. (2007). Teachers' scientific epistemological view: The coherence with instruction and students' views. Science Education, 91(2), 222-243. https://doi.org/10.1002/sce.20175

Turan, M. B. (2019). The relationship between university students' epistemological beliefs and teaching/learning conceptions. International Journal of Progressive Education, 15(1), 184-194. https://doi.org/10.29329/ijpe.2019.184.12

Wong, K. Y., Chan, K. W., \& Lai, P. Y. (2009). Revisiting the relationship of epistemological beliefs and conceptions about teaching and learning of pre-service teachers in Hong Kong. Asia-Pacific Education Researchers, 18(1), 1-19.

Yadav, A., \& Koehler, M. (2007). The role of epistemological beliefs in preservice teachers' interpretation of video cases of early-grade literacy instruction. Journal of Technology and Teacher Education, 15(3), 335-361.

Yılmaz, H., \& Şahin, S. (2011). Pre-service teachers' epistemological beliefs and conceptions of teaching. Australian Journal of Teacher Education, 36(1), 73-88. https://doi.org/10.14221/ajte.2011v36n1.6

Y1lmaz, M. (2014). The relationship between teacher candidates' learning styles and their conceptions about teaching and learning and their science teaching efficacy beliefs (Unpublished master's thesis). Abant İzzet Baysal University, Bolu, Turkey.

Yurdakul, B. (2015). Yapılandırmacılık [Constructivism]. In Ö. Demirel (Ed.), Eğitimde Yeni Yönelimler [New Directions in Education] (6th ed.). Pegem Akademi. 